\title{
MILITARY BROWNFIELDS IN THE CZECH REPUBLIC AND THE POTENTIAL FOR THEIR REVITALISATION, FOCUSED ON THEIR RESIDENTIAL FUNCTION
}

\author{
Jan HerciK ${ }^{1}$, Petr ŠimÁčeK ${ }^{1}$, ZdeněK SZCZyrba ${ }^{2}$, IRena SMOlovÁ ${ }^{2}$ \\ ${ }^{1}$ Department of Geography, Faculty of Natural Sciences, Masaryk University, Brno, Czech Republic \\ ${ }^{2}$ Department of Geography, Faculty of Natural Sciences, Palacký University, Olomouc, Czech Republic
}

Manuscript received: February 3, 2014

Revised version: March 13, 2014

\begin{abstract}
HerciK J., ŠimÁČeK P., Szczyrba Z., Smolová I., 2014. Military brownfields in the Czech Republic and the potential for their revitalisation, focused on their residential function. Quaestiones Geographicae 33(2), Bogucki Wydawnictwo Naukowe, Poznań, pp. 127-138, 3 tables, 7 figs. DOI 10.2478/quageo-2014-0021, ISSN 0137-477X.

ABSTRACT: One of the basic transformation processes of the period since 1989 has been that of demilitarisation. Among other things, one of its consequences is the emergence of abandoned military buildings and areas - so-called military brownfields. These kinds of brownfields have a large number of specific features to which their subsequent revitalisation must necessarily be adapted. Since a large number of these areas are situated within municipalities or are directly adjacent to them, it is essential for their revitalisation to be approached with great sensitivity. This contribution deals with chosen examples of Czech revitalised post-military areas with a special view to their residential function, which is presently their dominant functional use.
\end{abstract}

KEY wORDS: military brownfield, revitalisation, residential function, Czech Republic

Jan Hercik, Department of Geography, Faculty of Science, Palacký University, Olomouc, 17. listopadu 12, 77146 Olomouc, Czech Republic; e-mail: jan.hercik@upol.cz

\section{Introduction}

During the period of transformation after 1989 we can note many processes in the post-communist countries which have considerably changed their politics on the one hand and their societies and economies on the other. These processes involve de-industrialisation, de-agrarianisation and demilitarisation as a part of geopolitical changes (Matlovič et al. 2001). One of the common consequences of those three processes has been the appearance of abandoned and unused buildings and areas - brownfields. Obviously, we cannot consider brownfields as a purely Central European problem connected with changes after the fall of communism. But the speed of transfor- mation-related changes and thus the dynamics of the formation of brownfields have been exceptional in this area compared with other regions. In the literature, municipal and regional policies in the post-communist countries mostly focus on brownfields of an industrial character (e.g. Kuda, Smolová 2007; Bergatt Jackson et al. 2004, etc.). This is very logical if we take into account that the total area of this type of brownfields is the biggest one.

Apparently, less interest has been concentrated on brownfields formed as a consequence of the departure of armed forces (the army, border guards, etc.) from a territory - the so-called military brownfields. In the literature relatively few authors have been interested in this phenomenon 
so far. This issue is mostly viewed from the perspective of the revitalisation of brownfields as degraded areas or buildings, and of the potential of their regeneration for future economic use. The aspects often discussed in this respect involve soil decontamination and the overall redevelopment of the territory after the exodus of military forces as well as technical, urban, environmental, and social aspects associated with that (e.g. Jauhiainen 2002; Bagaeen 2006).

In the Czech Republic much has been written in recent years, the most important being the book by Šilhánková (2006). One should especially mention case studies mapping individual areas concerned (e.g. Bičan et al. 2006; Hercik et al. 2011). In other post-communist countries of Central and Eastern Europe case studies predominate as well. Among foreign authors interested in aspects of demilitarisation are, for example, Kozłowska (2005), Jarczewski and Kuryło (2009), and Simion-Melinte (2012), who provide a comprehensive view of the formation and revitalisation of military brownfields in Poland and Romania after the year 1990.

The objective of this article is to assess the possibilities of regeneration of military brownfields in the Czech Republic and use a few examples to demonstrate the suitability of their revitalisation for residential purposes. After all, in areas previously used by the army, this form of functional transformation belongs among the most frequent examples, not only in this country but also abroad (Bagaeen 2006; Šilhánková 2006; Simion-Melinte 2012). Another objective is to analyse the perception of this change in the utilisation of post-military areas by the population of the sites concerned (see Fig. 6) and to show the possibilities of their transformation for the purposes of new housing.

\section{Theoretical background}

The concept of brownfields is not new in the world. Some countries in Western Europe and the USA have had a lot of experience of brownfields for many decades, especially in connection with the massive de-industrialisation and transition to new industries or the internationalisation of production and services in the late 1960s and early 1970s. Gradually, the range of brownfields began to extend in connection with buildings formerly used for agricultural production or transport infrastructure, or abandoned military areas (Syms 1999; Litt, Burke 2002; Dixon 2006; Thornton et al. 2007; Wedding, Crawford-Brown 2007).

Brownfields are now a very frequent and topical subject not only for urban designers, architects and economists, but also for geographers, ecologists, and other professions. As stated by Sýkorová (2007), brownfields come to the fore especially in the context of sustainable development, disproportionate urban sprawl, and the revitalisation of city centres. The majority of authors approach brownfields as an issue of urban landscapes (e.g. Novosák, Szczyrba 2004), but it should be noted that they are connected not only with urban areas but also with the countryside, where we see significant degradation of previous economic activities (Svobodová, Věžník 2009).

Regarding brownfields, discussions of their regeneration in the context of the construction of new production or non-production sites on greenfield sites frequently appear in the literature. As emphasised by Frantál et al. (2013), the problem is of a fundamental nature, despite the growing political support at different levels from the European Commission, through national grant schemes, to local spatial development policies. It is still true that potential investors are primarily afraid of the ecological risks associated with brownfield regeneration and therefore they prefer greenfields when looking for suitable locations for their investments. Furthermore, as the authors show, regeneration projects of brownfields in the countries of the post-socialist bloc are primarily taken on by foreign investors, for whom a rapid return on capital is one of the key factors in their investment, and these projects are typically new commercial buildings and premises (shopping centres, offices, and housing projects). On the other hand, in countries with developed market economies, the regeneration of brownfield sites is more often connected with public-private partnership models (see Kalberer et al. 2005) and the projects that are implemented do not have a purely commercial nature.

In the process of the regeneration of brownfield sites we must also take into account their wider spatial context, i.e. not only local conditions that 
directly affect the possibilities of brownfield regeneration, but also factors operating at a higher hierarchical level (Dasgupta, Tam 2009; Frantál et al. 2013). The range of factors affecting development and the potential of brownfield regeneration is shown in Table 1. They include various levels of the hierarchical organisation of space: from institutional to economic and ecological up to social and demographic. Similar attempts to systematise factors of brownfield regeneration are a frequent subject of many publications (e.g. Nijkamp et al. 2002; Longo, Campbell 2007).

The origin of military brownfields is not exclusively connected with the geopolitical changes of the late 20th century, although these changes are essential for us in terms of the focus of this article. For example, in the 19th century, after the United Kingdom began to change its defence doctrine towards the strengthening of its geopolitical influence in Europe, British forces began leaving their naval fortresses. Another example involves changes in the military structure of the Austro-Hungarian Empire in the 19th century, when the fortifications around cities were found useless and the abandoned forts were subsequently redeveloped for urban purposes (Vienna, Brno, Hradec Králové, Olomouc, etc.).

At that time local authorities had to deal with that situation and utilise it for the development of their town in the best way they could. Contemporary political representatives should deal with brownfields (not only military ones) in a similar way. Brownfields should be understood as places for the potential development of a town.
Military brownfields have a range of specific features in comparison with their other types. Among the most important ones are the functional diversity of the buildings within sites (there could often be administrative and residential buildings, warehouses, garages, etc. at one site) and the location of the sites. Most military brownfields are situated either in the intra-urban area of municipalities or in their immediate neighbourhood.

In terms of the classification of areas according to their position, we can identify military brownfields situated inside urban areas and those in extra-urban areas of municipalities. Inside municipalities we can usually find multifunctional sites whose character predetermines further use of the buildings and area. Therefore the multifunctional character of a site combining residential, commercial and often educational, cultural, or manufacturing functions is usually maintained. The revitalisation of those post-military areas is a highly individual matter for each municipality and depends not only on the specific features of the area, but also on the needs of the municipalities and visions of local political leaders, or new owners of the property. Thus, we can find municipalities which have retained only a minimum number of facilities in the area in their ownership, together with engineering networks, and sold the rest to private investors (e.g. Hodonín in South Moravia). We can also find examples where municipalities have kept most of the property and they either administer it themselves or rent it out (e.g. Uherské Hradiště in South Moravia). The use of sites in extra-urban areas of municipali-

Table 1. Spatial scale of success factors of brownfield regeneration

\begin{tabular}{|l|c|}
\hline \multicolumn{1}{|c|}{$\begin{array}{c}\text { Factors } \\
\text { (spatial level) }\end{array}$} & \multicolumn{1}{c|}{ Characterisation } \\
\hline $\begin{array}{l}\text { General factors } \\
\text { (macro-level) }\end{array}$ & $\begin{array}{c}\text { associated with political, economic, or social climate - legislative instruments concern- } \\
\text { ing national or regional development policies; spatial planning strategies; economic } \\
\text { instruments such as bank loans, subsidies, tax benefits, and foreign direct investment; } \\
\text { regeneration management instruments including availability of information, databases, } \\
\text { tools, education, etc. }\end{array}$ \\
\hline $\begin{array}{l}\text { Location factors } \\
\text { (meso-level) }\end{array}$ & $\begin{array}{c}\text { geographical location within region, transport links, socio-demographic structure of } \\
\text { local population, economic potential, rates of business activities and unemployment, } \\
\text { and social capital, but also 'soft' factors, such as local political leadership, community } \\
\text { involvement, etc. }\end{array}$ \\
\hline $\begin{array}{l}\text { Site-specific factors } \\
\text { (micro-level) }\end{array}$ & $\begin{array}{c}\text { size of brownfield, its previous use, number of buildings and structures, soil quality } \\
\text { and extent of contamination, available infrastructure, ownership relations, actual price, } \\
\text { total costs of revitalisation, etc. }\end{array}$ \\
\hline
\end{tabular}

Source: Frantál et al. (2013). 
ties is slightly more complicated and depends on their distance from the municipality and their functional structure. Usually industrial zones are established here, the size of which in terms of the number of employees and their importance is determined by the size of the area itself. Among the most important projects of this type is the Triangel strategic industrial zone in Žatec, which has been developed on the territory of a former military air base. But generally these areas are minor industrial zones of local importance (e.g. the site at Vazačka near Bělá pod Bezdězem in the Central Bohemian Region).

In addition to specific features related to the function and location, we can find other ones, for example non-restoration of the military function in military brownfields. The way in which the ownership of military brownfields changes is also very specific. Compared with industrial brownfields, where what most frequently happens is a sale of the property directly to a new private owner, in the case of military brownfields currently the most common way to change ownership is a free transfer from the Army of the Czech Republic to the local government as unnecessary military property ${ }^{1}$. A contract of free transfer can indeed significantly restrict the new owner, the local government, as to possible ways in which the area can further be used. A condition of the non-commercial use of the property or the impossibility of sale to a third party for a certain time can be part of the contract in some cases. Nevertheless, municipalities gain large areas within their boundaries which often help to create a certain 'genius loci' of the wider locality (some buildings are even protected monuments) and can be significant zones of development.

Besides municipalities, the army transfers its unwanted property free to other organisational units of the State that have an appropriate use for it. The largest part of this dispensable immovable property is single buildings, which are then used as courthouses, offices, and other public institutions. Bigger areas account for only a small part, such as, for example, the military barracks in Kynšperk nad Ohří (Western Bohemia), in which a jail has been established, or the former military area of Jezová (part of the Ralsko mili-

Act No. 174/2003 Coll.

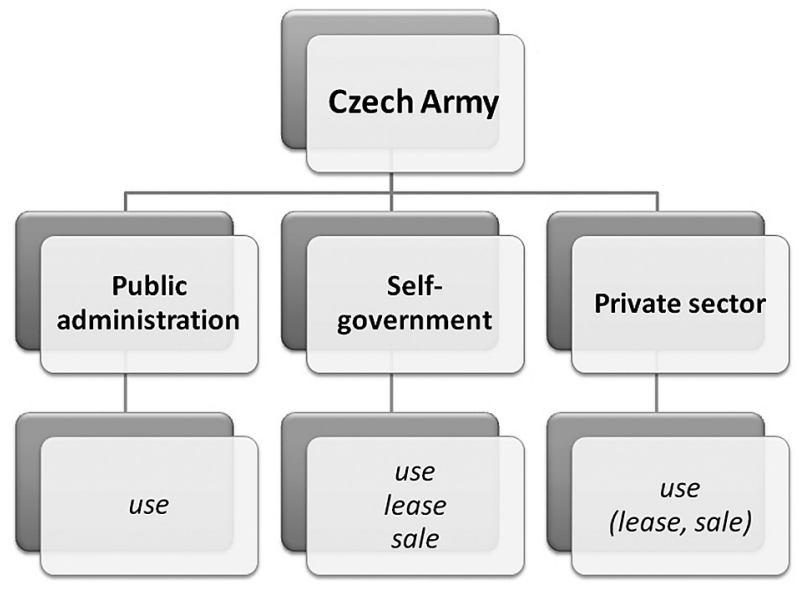

Fig. 1. Diagram of changes of the owners of post-military buildings and areas Source: authors' own compilation

tary training area), which has been rebuilt as a refugee camp of the Ministry of the Interior of the Czech Republic.

The last type of new owners of former military sites is private investors, to whom, however, this property is offered only when the previously-mentioned entities (local government, state government) are not interested in it properly². Another way for private or legal persons to acquire this property is by secondary purchase from municipalities. Municipalities very often sell free undeveloped spaces where new investors build, for example, new residential complexes (on the basis of a land-use plan or changes to it). On former military sites two categories of flats may appear: those owned by the municipality and those owned by private persons. Municipal flats offered for rent are in most cases reconstructed with the help of the State or the European budget. On the one hand, it is housing which is financially genuinely accessible and, on the other, it is housing determined for a specific group of people (e.g. starter flats, low-threshold flats, flats for underprivileged citizens, nursing homes, etc.).

\section{Methodology and data sources}

The primary source of data, not only about military brownfields in the Czech Republic, was the Search Study for the Location of Brownfields,

$\overline{2}$ Act No. 219/2000 Coll. 


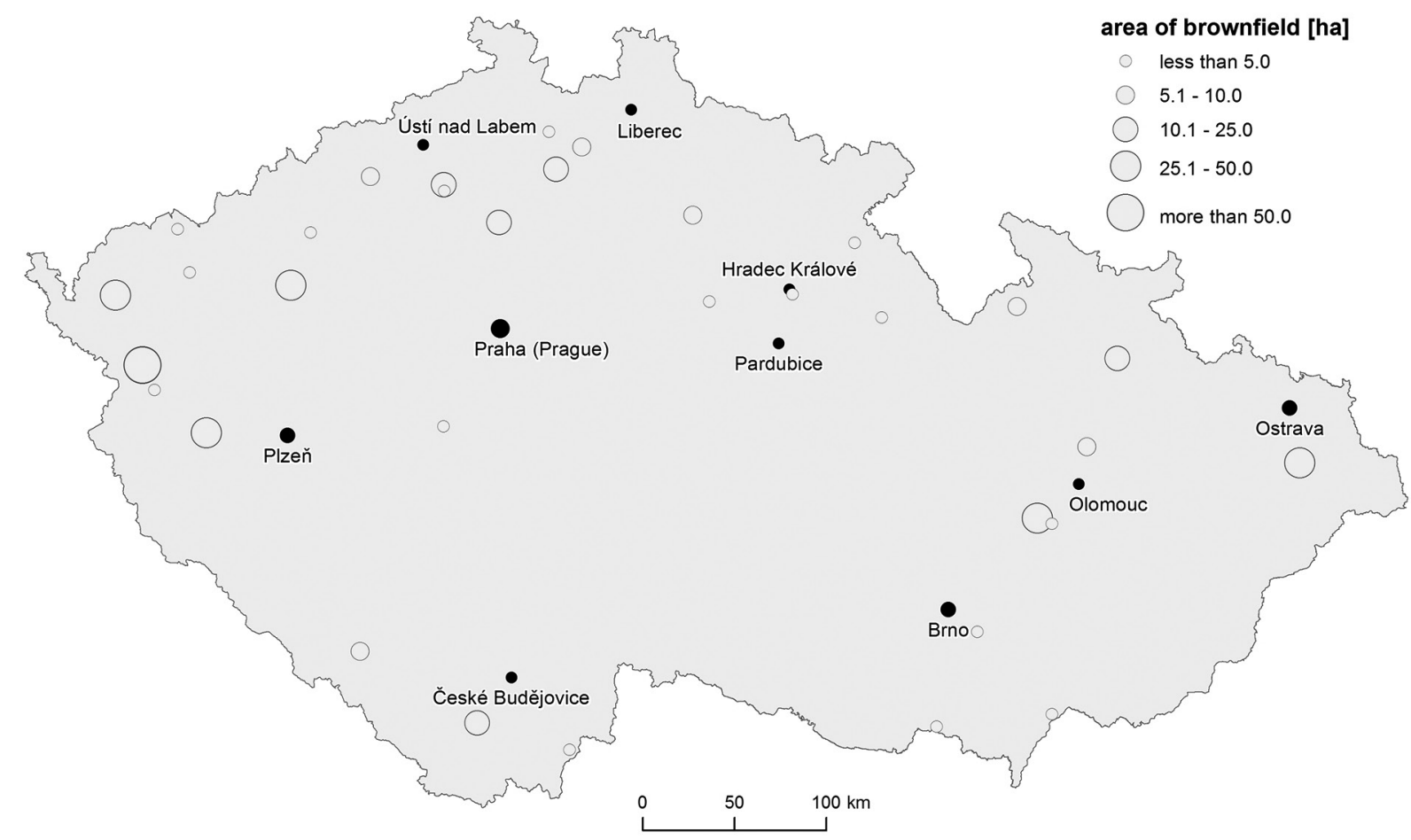

Fig. 2. Military brownfields offered to potential investors in the National Database of Brownfields (as of 15th January 2014) Source: CzechInvest (2014); authors' own compilation

established under the auspices of the CzechInvest Business Development Agency in the period 2005-2007. It was conducted in three consecutive steps. As steps 2 and 3 involved some selective factors, the results of step 1 are the most important with regard to the overall view of this issue. Within step 1, municipalities and villages were addressed and field research carried out, which resulted in the compilation of a catalogue of brownfields in all 13 regions. For each brownfield, the data of its location, original and appropriate future functions, status, size and other important aspects of its subsequent revitalisation were collected (Klusáček et al. 2013).

This research was subsequently used to establish the National Database of Brownfields, which serves primarily as a source of information for potential investors and now provides data on 2,355 brownfields all over the Czech Republic, including 151 military brownfields, which represent $6.4 \%$ of the total number of brownfields, and which occupied an area of 2,394 hectares, i.e. 23.2\% (CzechInvest 2008). The data in this database are, of course, not complete or unchanging, and therefore CzechInvest is gradually upgrading them. At present, CzechInvest offers poten- tial investors a database of almost 50 military brownfields in the Republic (Fig. 2), and in some municipalities there is more than one location.

The analytical part of the article discusses the monitoring of the functional changes in military brownfields through selected examples representing two basic components of the demilitarisation process in the Czech Republic: the withdrawal of Soviet troops (1) and the reduction of the Czech Army (2). In terms of methodology, the data and information were found during a detailed field survey in Milovice (1) and Uherské Hradiště (2). The survey was conducted in the spring and summer of 2012 and focused on the evaluation of selected parameters of revitalisation (costs of revitalisation, number of flats, number of new residents, etc.), so that the entire range of newly created facilities was included. The survey was conducted in cooperation with the local authorities from the municipal sphere.

In order to obtain feedback on how society perceives and evaluates the process of the revitalisation of military brownfields, a questionnaire survey was conducted among the residents of selected post-military sites (Fig. 3). The questionnaire was aimed at a wider context of perception 


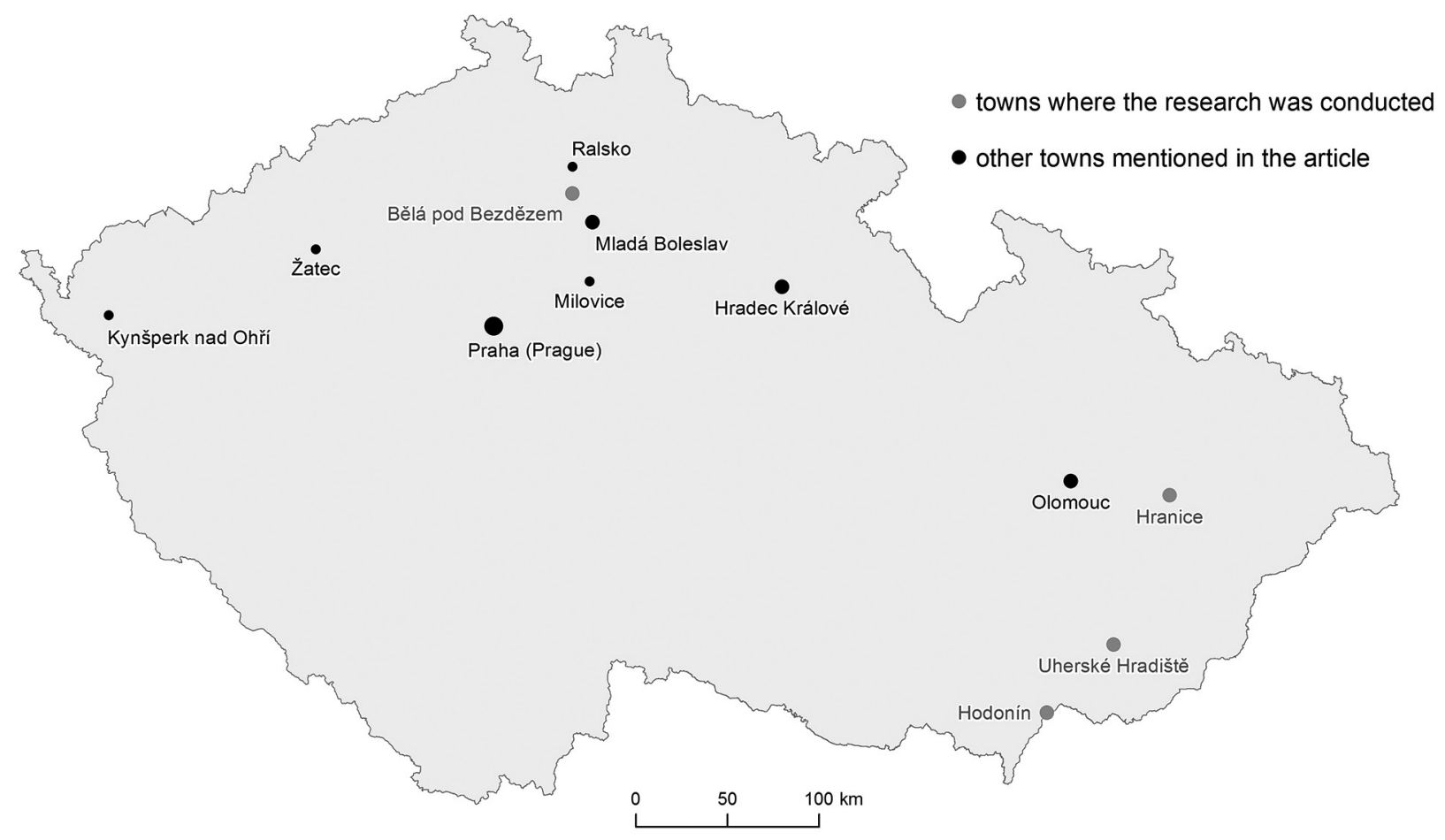

Fig. 3. Locations mentioned in the article Source: authors' own compilation

of the demilitarisation process, but also at more specific aspects associated with the withdrawal of the army from the region and further utilisation of the abandoned areas.

The survey included four municipalities: Bělá pod Bezdězem, Hodonín, Hranice, and Uherské Hradiště, all of which possessed former military areas belonging to the Czech Army where revitalisation had already been initiated (in all cases after 2000) and at least partially completed. The questionnaire survey in Bělá pod Bezdězem and Hranice took place in May 2010, while in Uherské Hradiště and Hodonín the research was carried out a year later, in May 2011. The representativeness of the data obtained in terms of quantity is shown in Table 2. In the course of the research, the emphasis was laid on the balance of the structure of the sample of the population that was in- terviewed both in terms of gender and in terms of age, education, or the location of the place of residence of the respondent within the municipality.

\section{Functional transformation of military brownfields in the Czech Republic: significant examples}

As already mentioned, 151 military brownfields with a total area of 2,394 hectares were found in 2007. In terms of their average size (15.9 ha), military brownfields were among the largest brownfield areas in the Czech Republic. The process of their recovery is long and has lasted for more than 20 years. During this time, hundreds

Table 2. Number of respondents in the municipalities concerned

\begin{tabular}{|l|c|c|c|}
\hline \multicolumn{1}{|c|}{ Town } & Number of respondents & Population & $\begin{array}{c}\text { Proportion of respondents to total } \\
\text { population of the town }\end{array}$ \\
\hline Bělá pod Bezdězem & 63 & 5,006 & $1.3 \%$ \\
\hline Hodonín & 150 & 25,472 & $0.6 \%$ \\
\hline Hranice & 206 & 19,158 & $1.1 \%$ \\
\hline Uherské Hradiště & 150 & 25,590 & $0.6 \%$ \\
\hline
\end{tabular}


of Czech municipalities have had to deal with new challenges in relation to the collapse of their military function, and many of them have undergone a successful transformation (measured by the extent of the newly created facilities on the site of the military brownfields).

For the purposes of this article, we selected two significant examples, each representing a different phase of the demilitarisation process in the Czech Republic. The first analyses the socio-functional transformation of a municipality which was part of a large training area of the Soviet Army on Czech territory until 1990 (Milovice). The second example illustrates a functional transformation in a place where the tradition of a military garrison dates back to the beginning of the 20th century (Uherské Hradiště).

\section{Areas left by the Soviet Army: the Milovice military training ground}

Some of the areas left by the Soviet Army have one very significant specific feature. Due to the fact that apart from 73.5 thousand soldiers ${ }^{3}$ (Pecka 1996), tens of thousands of their family members also lived on the territory of the former Czechoslovak Socialist Republic, in the areas which had the highest concentrations of Soviet troops entire residential quarters with a full range of civic facilities were created. Such areas can be found in military training sites (Ralsko, Milovice) and in bigger towns such as Olomouc or Mladá Boleslav.

As stated by Myrttinen (2003), the total area abandoned by the Soviet Army in the Czech Republic amounted to 34,400 hectares. The departure of the Soviet Army left many buildings of a military character but also hundreds of residential buildings with a total of 16,571 flats (Pecka 1996) of various sizes and in various states of repair. Most of them were transferred to the ownership of municipalities in 1990. Especially in areas situated inside towns, the process of their revitalisation and resettlement was relatively quick. The buildings were either transferred to the ownership of the municipalities or sold to private investors. Quite successful revitalisation of housing, financially supported by grant funds, mainly

Data from the beginning of 1990. from the Czech Republic and later also from the European Union, took place within the residential complexes inside the abandoned military training areas. The largest number of flats (more than 600) were in the Milovice military training ground, which was due to the fact that the Headquarters of the Central Group of Forces was located there. Thanks to the use of public grant funds, the revitalised housing became financially very attractive, especially to young families (for details see Kusovská 2012). The attractiveness of this location is increased by its relative proximity to the capital city, Prague (less than $30 \mathrm{~km}$ ).

After the withdrawal of the Soviet forces many buildings deteriorated for several years, and finally, in 1996, a great project was launched to refurbish the prefabricated houses abandoned by the military garrison in which not only the municipality of Milovice itself participated, but also the surrounding municipalities, various government institutions, and partly investors from the private sector.

The population of the municipality has grown relatively dynamically during the last two decades. While in 1989 Milovice had 1,088 permanently registered inhabitants (CZSO 2013), by the end of 2012 this figure had reached 10,042. Until 2003 this phenomenon was caused mainly by the migration of young families into the newly-refurbished apartments after the departure of the Soviets. Starting from 2004, large-scale building of apartments occurred in the municipality in originally non-residential parts of former military sites. Through this conversion 93 apartment units were completed in extensions to the existing residential buildings. In the same year 68 more dwellings were also completed as a result of construction changes to originally non-residential buildings. To illustrate, in the previous seven-year period (1997-2003) only a total of 16 new dwellings were completed in the municipality, but the number of residents more than doubled to almost 5,500 . While the share of dwellings completed in Milovice in 2004 reached 18\% of all the dwellings completed in the district of Nymburk, in 2007 this value was as high as $79 \%$. The increase in the number of dwellings is also related to the multiple increase in the number of inhabitants. Generally speaking, the population of Milovice directly correlates with the number of 
renovated apartments and dwellings newly completed in the originally military facilities. This rapid growth is due to suitable conditions for the reconstruction or new construction of apartment and family houses, and to the municipality's prized location in the wider hinterland of the capital city, Prague.

\section{Sites left by the Czech Army: the military barracks in Uherské Hradiště}

The abandonment of military areas by the Czechoslovak or, later, Czech Army is connected with the gradual process of the democratisation, integration, and transformation of the army (Rašek 2005). During this process the number of soldiers and civic employees has been gradually reduced $\left(\mathrm{I}_{2009 / 1993}=0.54\right)$, as has the number of places where the army was located. In the case of military garrisons, there was a decrease from 183 to 30 between 1993 and 2008. Besides the liquidation of garrisons, smaller buildings and areas were also left, but they are only of insignificant importance from the point of view of regional development. As mentioned above, the majority of those areas were transferred to municipalities for free. They could then draw special grants from the State or European budget for their revitalisation. The programme of the Ministry of Regional Development entitled "Support for the revitalisation of former military sites" is focused directly on the revitalisation of post-military areas; for example, in 2011, grants of more than CZK 170 million were paid out from this fund to municipalities for projects totalling more than CZK 310 million (Ministry of Regional Development 2012).

The town of Uherské Hradiště also drew on this fund for the revitalisation of the former military barracks. It obtained this area in 2002 through a free transfer (Bičan et al. 2006). The future use of the site was partly determined by its location and the character of the buildings. As shown in Fig. 4, four major functions have gradually emerged: (1)

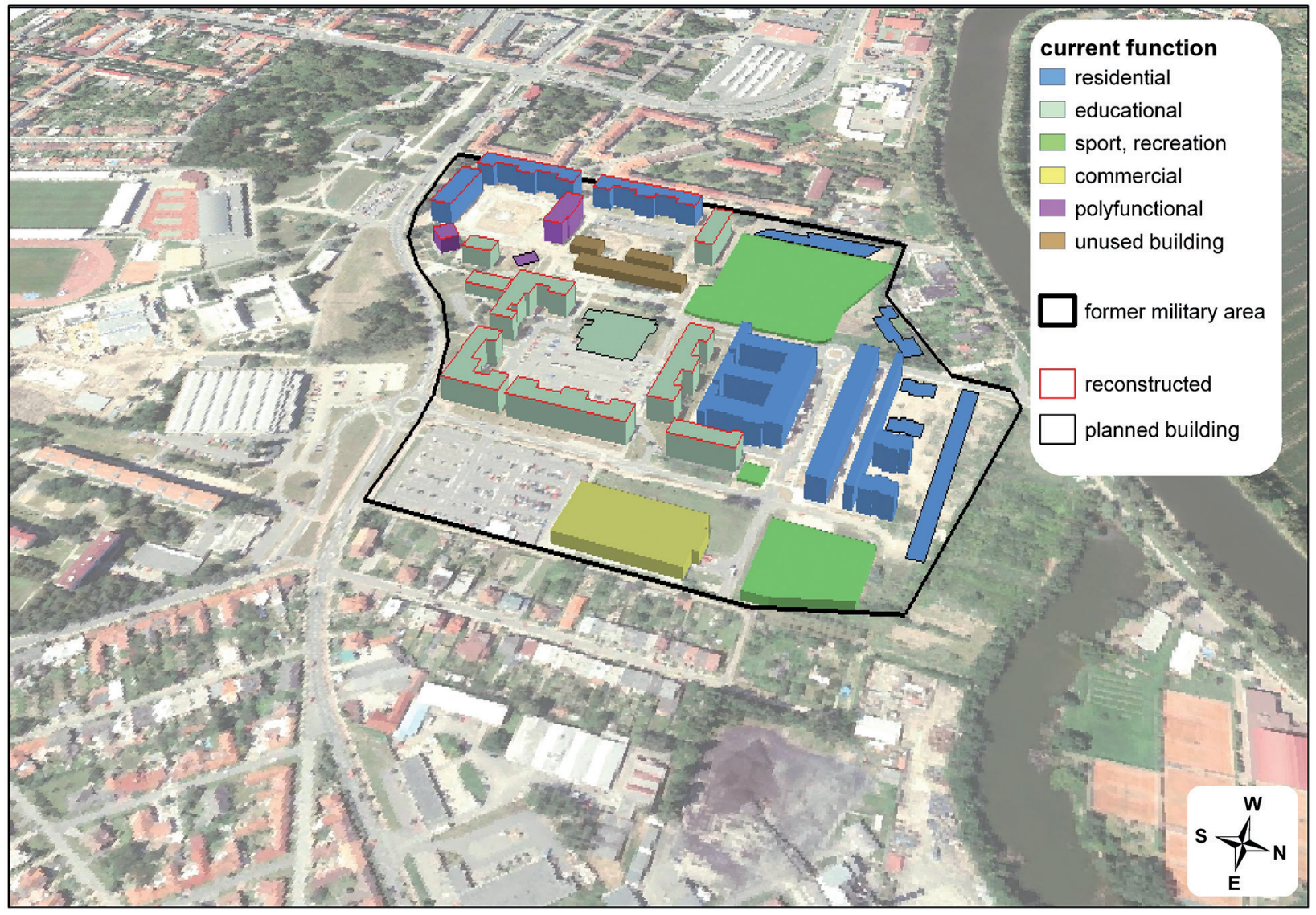

Fig. 4. Functional use of the former barracks in Uherské Hradiště Source: orthophoto by Geoportal ČÚZK (2012); authors' own processing 
commercial (the Kaufland hypermarket predominates here); (2) recreational (a park and tennis courts); (3) educational and cultural (a faculty of Tomáš Bat'a University, etc.), and (4) residential. It is the residential function that occupies the largest area. There are both revitalised buildings that date back to the beginning of the 1930s (Coupek et al. 1990), and new development projects that are concentrated mainly in the northern part of the area near the Morava river, where so far more than 150 housing units have been built (Hercik et al. 2011). The revitalisation of housing was performed by the town of Uherské Hradiště with the financial support of the state budget of the Czech Republic. These flats were designed as so-called starter flats and sheltered housing (more than 80 flats).

\section{Residential function of former military sites: an analysis of perception}

It is obvious from the text above that one of the most frequent uses of revitalised military brownfields is their residential function. This is not only the most frequent function but also the most necessary one, and therefore most positively evaluated by the public. This claim is based on the conclusions of the survey performed in four towns of the Czech Republic (Bělá pod Bezdězem, Hodonín, Hranice, and Uherské Hradiště) in the years 2010 and 2011. In Hodonín and Uherské Hradiště, the post-military sites are situated in the intra-urban area of the municipalities not far from the centre; they have largely been revitalised. The situation in Hranice is quite different: the site is situated on the edge of its urban housing development and still awaits full revitalisation. The final locality surveyed was the Central Bohemian town of Bělá pod Bezdězem. There we can find two completely different sites; the only fact that they have in common is that they are both situated in the extra-urban area of the municipality. The first site is a military barracks of the Army of the Czech Republic (nowadays revitalised for the needs of a small industrial zone) and the second site is an extensive area left by the Soviet Army (which still awaits full revitalisation).

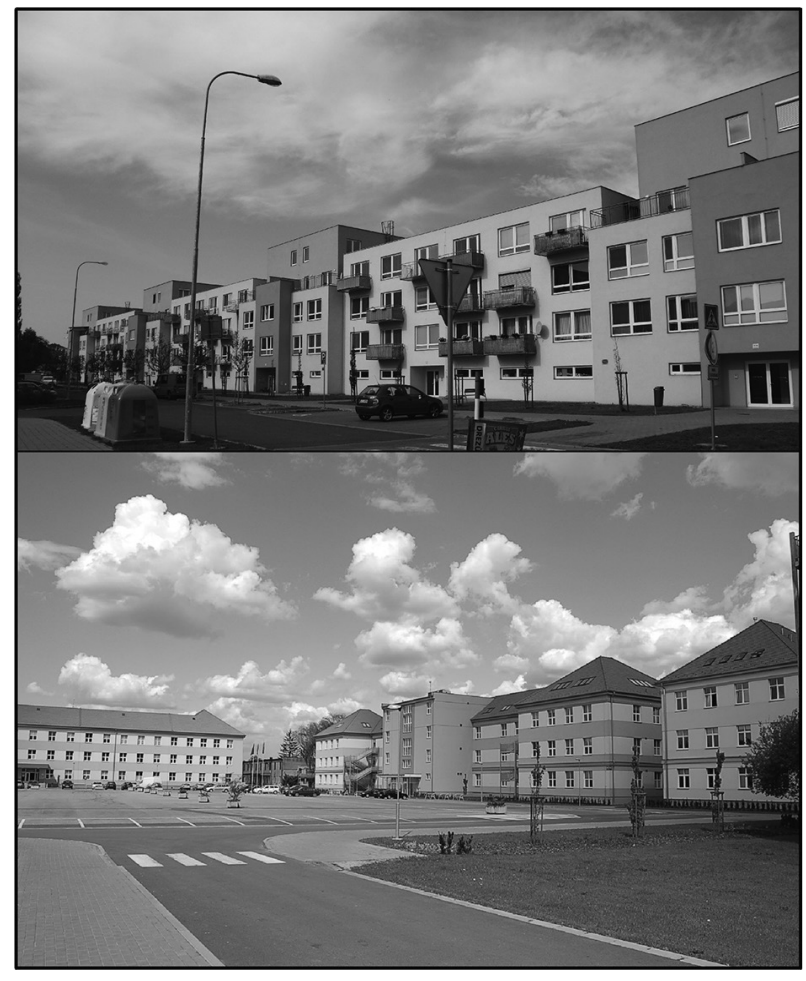

Fig. 5. Top: New residential complex in the post-military area in Uherské Hradiště (photo: Hercik 2012)

Bottom: Revitalised buildings in the post-military area in Uherské Hradiště (photo: Hercik 2011)

At this point, the authors decided to present only a part of the survey results showing the opinions of the residents of these municipalities, who perceive aspects of the demilitarisation process with all its consequences very sensitively.

One of the most important questions in the questionnaire was about the way in which the military brownfields should be used with regard to the location of the site within the municipality. The percentage of answers is shown in Fig. 6 . Focusing on the areas awaiting revitalisation, we find that they are both, despite their different locations, at least partially appropriate for residential use. These areas have buildings of a multifunctional character, so their original residential function could only partly be restored. In both cases the residential function was marked by the respondents as the most suitable. There are differences with regard to the other preferred functions, where the responses are often directly connected with the character of particular sites (area in the middle of a forest, area near the railway station, residential and manufacturing buildings). 


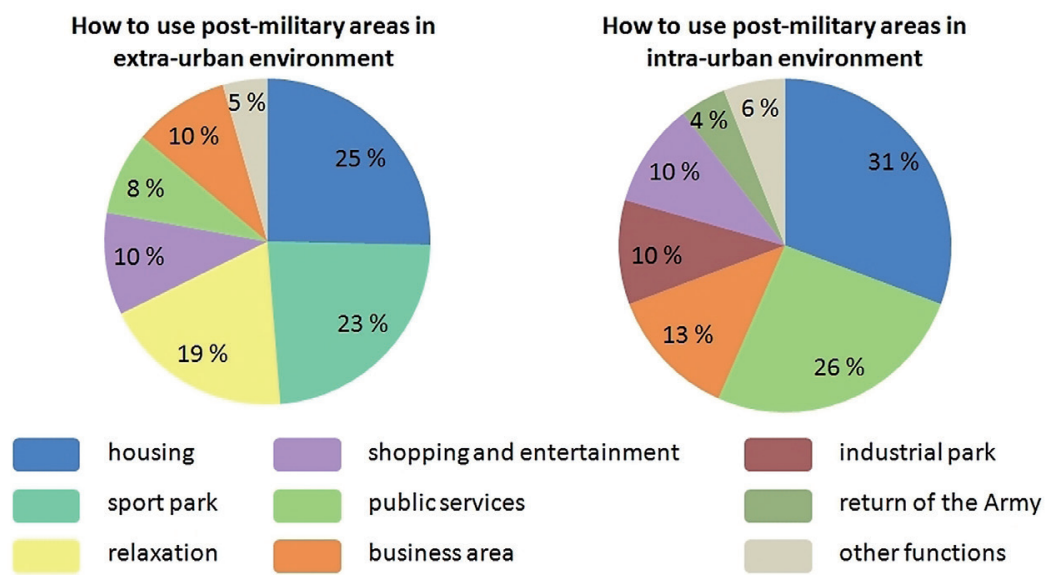

Fig. 6. Partial results of the research on how to use post-military areas in extra- and intra-urban environments Source: authors' own research

If we look at the results of the research on the possibilities of revitalisation of military brownfields that were positively evaluated by the citizens (this was a separate question), we come to the conclusions shown in Fig. 7. The respondents had a choice of more than one of the suggested answers. The fact that the residential function is the one most frequently selected probably reflects the opinion of the population about the situation of the residential market in these towns. Any newly built or renovated residential buildings appear to be a welcome opportunity to enhance the quality of housing.

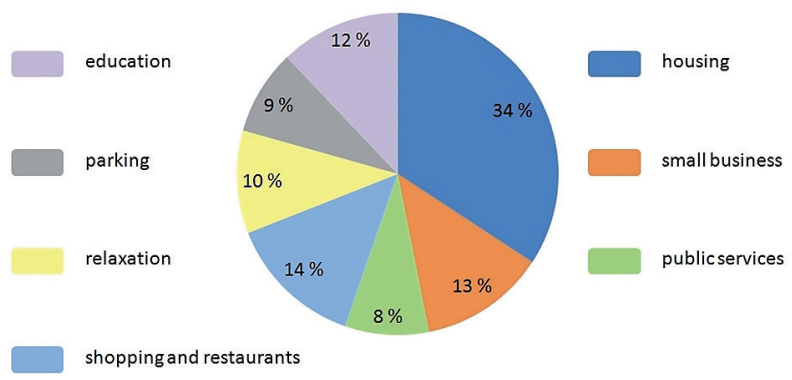

Fig. 7. Partial results of the research on positively rated functions of post-military areas in the intra-urban environment Source: authors' own research
The last section of the questionnaire aimed to assess the attractiveness of the revitalised areas in terms of their new functions as perceived by the residents of the municipality. Each respondent evaluated the selected functions on a scale of 1 to 5 , where 1 meant "very attractive" and 5 meant "unattractive". The resulting value (mark) for each function was established as the arithmetical mean of all the input values of possible functional uses. A summary of the resulting values is shown in Table 3.

There is an interesting difference in the evaluation of the attractiveness of the revitalised areas in terms of housing across the municipalities surveyed. While in Hodonín, Hranice, and Uherské Hradiště this possible purpose of revitalisation is perceived most positively (or in the case of Hranice as the second most attractive option), in Bělá pod Bezdězem this option seems to be the least attractive to the local people. On the basis of our interviews with residents, we come to the conclusion that the attractiveness of housing depends fundamentally on two determinants. One is the intended type of dwelling and the other, perhaps

Table 3. Summary of the resulting average values for functional uses in terms of their attractiveness to local residents

\begin{tabular}{|l|c|c|c|c|}
\hline \multicolumn{1}{|c|}{ Function / Place } & Bělá pod Bezdězem & Hodonín & Hranice & Uherské Hradiště \\
\hline housing & 2.9 & 1.8 & 2.0 & 1.6 \\
\hline leisure & 2.3 & 2.6 & 3.1 & 2.4 \\
\hline business & 1.9 & 2.1 & 1.8 & 2.5 \\
\hline shopping & - & 2.7 & 2.7 & 2.3 \\
\hline education & - & - & 2.2 & 1.6 \\
\hline
\end{tabular}

Source: authors' own research 
more important, the location of the area within the internal structure of the municipality. While in Hodonín and Uherské Hradiště the newly built or renovated apartments for medium- and low-income households were located close to the very centre of the city, in Hranice the location is on the outskirts of the town, and, in addition, in relatively close proximity to the railway station and the adjacent industrial zone. In the case of Bělá pod Bezdězem, the low attractiveness for dwelling purposes was mainly due to the relatively long distance of the area from the centre of the municipality, which caused the mean value of the score for housing to be significantly worse than in the other towns.

\section{Conclusions}

A large number of abandoned military sites and objects, called military brownfields, appeared as a result of the reduction of the armed forces on the territory of the former Czechoslovakia (or the current Czech Republic) after 1989. These types of brownfields have a number of specific features which significantly influence the potential for revitalisation of these properties. One of the basic ones is the functional heterogeneity within individual areas. In many areas, which can be often found in town centres, there are buildings which are, by their nature, predestined for a residential function. This function is one of the most common and most desired among the inhabitants as a result of the revitalisation of post-military areas. Not only is the refurbishment of original barracks buildings and apartment houses built for officers and their families (houses left by the Soviet army) often used for creating new flats, but so is the conversion of buildings which formerly had completely different functions than a residential one. Last but not least, there also appear completely new buildings (in most cases as part of development projects of private investors).

The revitalisation of military brownfields is significantly supported by funding from government or international aid programmes, either those directly intended for the revitalisation of former military areas or those that aim to develop housing. Thus, thanks to the revitalisation of former military sites in the Czech Republic, so far hundreds of new dwellings have been created, which has greatly boosted the development of the municipalities concerned.

On the basis of the research performed, it is possible to deduce basic preferences of the population in terms of their perception of the impact of the revitalisation of military brownfields. The respondents rated the transformation of the former military buildings into residential facilities in a unanimously positive way and welcomed the opportunity to improve the quality of housing in the municipality. At the same time, let us add that although the residential function is the most popular way of utilising military brownfields in a new way, it is necessary to approach this finding with caution and always assess individual areas separately (as shown by the example of Bělá pod Bezdězem).

\section{References}

Act No. 219/2000 Coll. on the property of the Czech Republic and its representation in legal relationships.

Act No. 174/2003 Coll. on the transfer of some surplus military property and assets, administered by the Ministry of the Interior, from the ownership of the Czech Republic to the ownership of territorial authorities.

Bagaeen S.G., 2006. Redeveloping former military sites: Competitiveness, urban sustainability and public participation. Cities 23(5): 339-352.

Bergatt Jackson J. et al., 2004. Brownfields snadno a lehce. IURS, Prague.

Bičan J., Holý A., Šupka P., 2006. Revitalizace bývalého kasárenského areálu v Uherském Hradišti. Urbanismus a územní rozvoj 9(2): 17-21. Ústav urbanismu a územního rozvoje, Brno.

CzechInvest, 2008. Národní strategie regenerace brownfieldů. Online: http://www.czechinvest.org/data/files/nsb595.pdf (accessed 30 December 2013).

CzechInvest, 2014. National database of brownfields. Online: http://www.brownfieldy.org/brownfields-list/ (accessed 19 January 2014).

CZSO, 2013. Czech Statistical Office - Demographic database of municipalities in the Czech Republic: Districts of Hodonin, Mladá Boleslav, Nymburk, Přerov, Uherské Hradiště. Online: http://www.czso.cz/cz/obce_d/index.htm (accessed 10 January 2014).

Dasgupta S., Tam E., 2009. Environmental review: A comprehensive review of existing classification systems of brownfield sites. Environmental Practice 11(4): 285-300.

Dixon T., 2006. Integrating sustainability into brownfield regeneration: Rhetoric or reality? - An analysis of the UK development industry. Journal of Property Research 23(3): 237-267.

Čoupek J., Šnajdr J., Paule O., 1990. Vojsko v Uherském Hradišti. Uherské Hradiště. 
Frantál B., Kunc J., Nováková E., Klusáček P., Martinát S., Osman R., 2013. Location matters! Exploring brownfields regeneration in a spatial context (case study of the South Moravian Region, Czech Republic). Moravian Geographical Reports 21(2): 5-19.

Geoportal ČÚZK, 2012. Czech Office for Surveying, Mapping and Cadastre - Web Map Service of orthophoto.

Hercik J., Šerý O., Toušek V., 2011. Post-military areas in the Czech Republic and their revitalization - examples of the towns of Hodonín and Uherské Hradiště. Geographica 42(2): 107-119. Palacký University Olomouc, Olomouc.

Jarczewski W., Kuryło M., 2009. Rewitalizacja terenów powojskowych (Revitalisation of post-military sites). In: Jarczewski W. (ed.), Przestrzenne aspekty rewitalizacji śródmieścia, blokowiska, tereny poprzemystowe, pokolejowe $i$ powojskove. Instytut Rozwoju Miast, Kraków: 243-289.

Jauhiainen J. S., 2002. Defence restructuring and conversion. In: Taipale I. et al. (eds), War or health. A reader. ZN Spon, London: 580-588.

Kalberer A., Klever S.F., Lepke T. (eds), 2005. The future lies on brownfields. Federal Environmental Agency. Online: http:// www.umweltbundesamt.de/ sites/ default/ files/medien/ publikation/long/3051.pdf (accessed 3 January 2014)

Klusáček P., Krejčí T., Martinát S., Kunc J., Osman R., Frantál B., 2013. Regeneration of agricultural brownfields in the Czech Republic - Case study of the South Moravian Region. Acta Universitatis Agriculturae et Silviculturae Mendelianae Brunensis 61(2): 549-561.

Kozłowska E., 2005. Miasto po likwidacji garnizonu (A city after the liquidation of a garrison). Studia Regionalne $i$ Lokalne 21(3): 97-112. Uniwersytet Warszawski, Warszawa.

Kuda F., Smolová I., 2007. Technické a geografické aspekty integrace neprůmyslových brownfieldu do území. Ostrava: VŠBTUO.

Kusovská M., 2012. Vliv vojenského újezdu na populační vývoj města Milovice. Demografie 54(1): 14-23. CZSO, Prague.

Litt J. S., Burke T. A., 2002. Uncovering the historic environmental hazards of urban brownfields. Journal of Urban Health 79(4): 464-481.

Longo A., Campbell D., 2007. What are the determinants of brownfields regeneration? An analysis of brownfields in England. In: Proceedings of the Conference on the Science and Education of Land Use: A Transatlantic, Multidisciplinary and Comparative Approach. Washington, DC, USA, 24-26 September 2007. Online: http://nercrd.psu.edu/taluc/ (accessed 29 December 2013).

Matlovič R., Ira V., Sýkora L., Szczyrba Z., 2001. Procesy transformacyjne struktury przestrzennej miast postkomunistycznych (na przykładzie Pragi, Bratysławy, Ołomuńca oraz Preszowa) (Transformation of the spatial structure of post-communist towns: the case of Prague, Bratislava, Olomouc and Presov). In: Jażdżewska I. (ed.),
Miasto postsocjalistyczne - organizacja przestrzeni miejskiej $i$ jej przemiany (II). XIV Konwersatorium Wiedzy o Mieście, Uniwerystet Łódzki, Łódź: 243-251.

Ministry of Regional Development, 2012. Podpora revitalizace bývalých vojenských areálù. Online: http:/ / www.mmr.cz/ getdoc/5ba69714-63e3-4f1c-bb64-8eeed508e5e5/Podpora-revitalizace-byvalych-vojenskych-arealu (accessed 28 December 2013).

Myrttinen H., 2003. Base conversion in Central and Eastern Europe. BICC paper 30. Bonn: BICC.

Nijkamp P., Rodenburg C.A., Wagtendonk A.J., 2002. Success factors for sustainable urban brownfield development: A comparative case study approach to polluted sites. Ecological Economics 40(2): 235-252.

Novosák J., Szczyrba Z., 2004. Frýdek-Místek: konverze tradičních průmyslových ploch, širší vztahy geografické struktury. Urbanismus a územní rozvoj 7(2): 36-45. Ústav urbanismu a územního rozvoje, Brno.

Pecka J., 1996. Odsun sovětských vojsk z Československa 19891991. Ústav pro soudobé dějiny, Prague.

Perić A., Furundžić D., 2013. Collaboration in the brownfield regeneration process - legally binding or informal approach? In: Schrenk M., Popovich V.V., Zeile P., Elisei P. (eds), Proceedings REAL CORP 2013: PLANNING TIMES: 181-188. Online: http://www.corp.at/archive/ CORP2013_169.pdf (accessed 13 January 2014).

Rašek A., 2005. Patnáct let polistopadové armády. Listy 2005(1). Online: http:/ / www.listy.cz/ archiv.php?cislo= 051\&clanek $=010505$ (accessed 8 January 2014).

Simion-Melinte C., 2012. Reconversion of military sites into business incubators and business support centers - the European experience. Business Excellence and Management 2(2): 79-86. Online: http://beman.ase.ro/ no22/ 7.pdf (accessed 11 January 2014).

Svobodová H., Věžník A., 2009. To the problems of agricultural brownfields in the Czech Republic, case study of the Vysočina region. Agricultural Economics 55(11): 550556. Prague: Česká akademie zemědělských věd.

Syms P., 1999. Redeveloping brownfield land. The decision-making process. Journal of Property Investment $\mathcal{E}$ Finance 17(5): 481-500.

Sýkorová I., 2007. Pražské brownfields: př́ležitost i hrozba pro rozvoj metropole. Geografie-Sborník České geografické společnosti 112(3): 250-265.

Šilhánková V. et al., 2006. Rekonverze vojenských brownfields. University of Pardubice, Pardubice.

Thornton G., Franz M., Edwards D., Pahlen G., Nathanail P., 2007. The challenge of sustainability: incentives for brownfield regeneration in Europe. Environmental Science \& Policy 10(2): 116-134.

Wedding G.Ch., Crawford-Brown D. 2007. Measuring site-level success in brownfield redevelopments: A focus on sustainability and green building. Journal of Environmental Management 85(2): 483-495. 